\title{
Analisis faktor-faktor yang mempengaruhi permintaan kain batik Jambi di Kelurahan Mayang Mangurai Kecamatan Alam Barajo Kota Jambi
}

\author{
Anisa Dinda Lestari* ; Zulfanetti; Hardiani \\ Prodi Ekonomi Pembangunan, Fak Ekonomi dan Bisnis,Universitas Jambi \\ *E-mail korespondensi: anisadindalestari153@gmail.com
}

\begin{abstract}
The purpose of this study was (1) to analyze consumer characteristics of Jambi batik cloth based on the amount of demand for Jambi batik cloth in Mayang Mangurai Village, Alam Barajo District, Jambi City (2) to analyze the effect of Jambi batik cloth prices, consumer income, and prices of substitute goods on cloth demand. Jambi batik in Mayang Mangurai Village, Alam Barajo District, Jambi City. The method used in this study is a survey method using primary data obtained from questionnaires and direct interviews. The data analysis method used was descriptive and quantitative analysis methods with multiple linear regression analysis. The results of the study indicate that (1) the average age of consumers of Jambi batik cloth in Mayang Mangurai Village is 42 years, the last education average of Jambi batik cloth consumers is S1, the average job of Jambi batik cloth consumers is as a civil servant, the average consumer of Jambi batik cloth has a family of 4 people, and the average income earned by consumers of Jambi batik cloth is Rp.4.240.000 on average per month in a year; and (2) simultaneously and partially independent variables, the price of Jambi batik cloth, consumer income and the price of substitute goods have a significant effect on the demand for Jambi batik cloth in Mayang Mangurai Village, Alam Barajo District, Jambi City.
\end{abstract}

Keywords: Demand, Price, Income, Price of Substitute Goods

\begin{abstract}
Abstrak
Tujuan penelitian ini adalah (1) untuk menganalisis karakteristik konsumen kain batik Jambi berdasarkan jumlah permintaan kain batik Jambi di Kelurahan Mayang Mangurai Kecamatan Alam Barajo Kota Jambi (2) untuk menganalisis pengaruh harga kain batik Jambi, pendapatan konsumen, dan harga barang substitusi terhadap permintaan kain batik Jambi di Kelurahan Mayang Mangurai Kecamatan Alam Barajo Kota Jambi. Metode yang digunakan dalam penelitian ini adalah metode survei dengan menggunakan data primer yang diperoleh dari kuesioner dan wawancara langsung. Metode analisis data yang digunakan metode analisis deskriptif dan kuantitatif dengan analisis regresi linear berganda. Adapun hasil penelitian menunjukkan bahwa (1) ratarata umur konsumen kain batik Jambi di Kelurahan Mayang Mangurai adalah 42 tahun, rata-rata pendidikan terakhir konsumen kain batik Jambi yaitu S1, rata-rata pekerjaan yang dimiliki konsumen kain batik Jambi adalah sebagai PNS, rata-rata konsumen kain batik Jambi memiliki jumlah anggota keluarga 4 orang, dan rata-rata pendapatan yang diperoleh konsumen kain batik Jambi adalah Rp.4.240.000 rata-rata per bulan dalam setahun; dan (2) secara simultan dan parsial variabel independen harga kain batik Jambi, pendapatan konsumen dan harga barang substitusi berpengaruh signifikan terhadap permintaan kain batik Jambi di Kelurahan Mayang Mangurai Kecamatan Alam Barajo Kota Jambi.
\end{abstract}

Kata kunci : Permintaan, Harga, Pendapatan, Harga barang substitusi 


\section{PENDAHULUAN}

Industri kecil dan menengah (IKM) merupakan salah satu bentuk strategi alternatif untuk mendukung pengembangan perekonomian dalam pembangunan jangka panjang di Indonesia. Perannya terhadap pemerataan dan kesempatan kerja bagi masyarakat serta sumbangsih terhadap penerimaan devisa telah membuktikan bahwa usaha kecil tidak hanya aktif namun produktif. Pada konteks yang lebih luas keberadaan akan industri kecil dan menengah dapat memberikan sumbangan yang besar terhadap pertumbuhan pembangunan nasional. Dewasa ini pembinaan dan pengembangan industri kecil dan menengah merupakan topik penting yang harus terus dikaji, disempurnakan dan ditingkatkan agar penangananya lebih efektif. Secara khusus hal tersebut ditujukan kepada upaya untuk mengoptimalkan pembinaan dalam rangka pengembangan industri kecil dan menengah (Megasari, 2014).

Industri kecil dan menengah (IKM) dalam perekonomian di indonesia sangat potensial untuk dikembangkan, karena peranan industri kecil dan menengah di perekonomian nasional terhitung mencapai 60,34 persen (Simorangkir, 2018).Industri kecil dan menengah (IKM) yang ada di Indonesia saat ini sangat banyak mulai dari industri logam dan elektronika, industri bahan bangunan, industri kerajinan, industri pangan, dan industri sandangtermasuk industi kain batik. Industri kain batik banyak tersebar di bebagai daerah seperti di daerah Jawa, Kalimantan, Bali,Palembang dan daerah-daerah lainnya termasuk industri kain batik di Provinsi Jambi.

Tabel 1. Industri kecil menengah (IKM) dan kerajinan rumah tangga di Provinsi Jambi tahun 2010 dan 2016

\begin{tabular}{ccccc}
\hline Tahun & $\begin{array}{c}\text { Jumlah } \\
\text { Perusahaan } \\
\text { (Unit) }\end{array}$ & $\begin{array}{c}\text { Tenaga Kerja } \\
\text { (Orang) }\end{array}$ & $\begin{array}{c}\text { Nilai Investasi } \\
\text { (Juta) }\end{array}$ & $\begin{array}{c}\text { Nilai } \\
\text { Produksi } \\
\text { (Juta) }\end{array}$ \\
\hline 2010 & 17.800 & 48.400 & 59.967 .075 & 192.865 .650 \\
2016 & 27.866 & 70.367 & 108.748 .832 & 298.225 .000 \\
\hline $\begin{array}{c}\text { Rata-rata } \\
\text { pertumbuhan } \\
\text { per tahun (\%) }\end{array}$ & $\mathbf{7 . 3 9 1}$ & $\mathbf{5 . 6 4 5}$ & $\mathbf{1 1 . 1 4 7}$ & $\mathbf{6 . 6 7 7}$ \\
\hline Sumber : Dinas Perindustrian dan Perdagangan Provinsi Jambi, 2017 (diolah)
\end{tabular}

Berdasarkan Tabel 1 dapat diliah bahwa dari rata-rata pertumbuhan tersebut untuk jumlah produksi, tenaga kerja, nilai investasi dan nilai produksi dari tahun 2010-2016 terjadi peningkatan. Kondisi ini menunjukkan bahwa dalam memberdayakan/memandirikan ekonomi sektor industri kecil dan menengah di Provinsi Jambi potensial untuk dikembangkan dan diprioritaskan.

Menurut Zulfanetti dkk (2017) Sentra industri kecil dan menengah (IKM) di Provinsi Jambi salah satunya adalah industri kain batik Jambi.Batik Jambi termasuk salah satu batik yang diakui oleh UNESCO pada tanggal 2 Oktober 2009 sebagai warisan budaya tak benda yang harus dilestarikan dan dikembangkan. Kondisi ini menjadikan bisnis pemasaran batik Jambi semakin marak. Batik Jambi merupakan salah satu asset nasional yang tidak kalah bersaing karena memiliki keunikan, bernuansa etnik, tradisional dan klasik. Industri kecildan menengah batik Jambi beberapa tahun terakhir ini mendapat perhatian yang cukup antusias dari masyarakat Jambi sendiri maupun masyarakat nasional, seiring berkembangnya perekonomian Jambi dengan makin ramainya jumlah penduduk dan wisatawan lokal maupun mancanegara yang berkunjung ke Jambi mengakibatkan permintaan terhadap kainbatik Jambi menunjukkan kondisi peningkatan. 
Perkembangan permintaan kain batik di Jambi secara umum meningkat, hal ini dapat dilihat dari permintaan kain batik yang tinggi karena selain digunakan sendiri juga banyak untuk dijadikan oleh-oleh dan cinderamata. Selain itu peningkatan permintaan kain batik Jambi juga dapat dilihat dari omset yang didapat pengrajin batik Jambi yang bisa mencapai 10 juta perbulannya (Inun, 2017). Menurut Asosiasi Batik Jambi, dari 97 unit usaha batik Jambi saat ini dalam per bulan permintaan kain batik Jambi kurang lebih mencapai 100 meter per bulan dari total keseluruhan 97 unit usaha, hal ini tergantung dengan unit usahanya yaitu makin besar unit usaha tersebut seperti usaha batik Berkah dan batik Azmiah maka makin banyak permintaan kain batik Jambi (Asbaja, 2018).

Menurut Soraya (2015) permintaan kain batik Jambi pada beberapa tahun ini meningkat, hal tersebut dilihat dari peningkatan omset yang didapat pengrajin kain batik Jambi. Banyaknya konsumen yang membeli kain batik Jambi sebagian besar adalah tamu dari luar provinsi untuk dijadikan oleh-oleh dan cinderamata untuk dibawa pulang ke daerah asalnya.Masyarakat Jambi yang membeli kain batik Jambi relatif sedikit dibandingkan dengan konsumen luar, artinya permintaan kain batik Jambi lebih banyak dibeli oleh kosumen luar, masyarakat Jambi sendiri hanya orang-orang tertentu saja yang membeli kain batik Jambi yaitu sebagian besar hanya orang-orang yang bekerja sebagai pegawai negeri dan swasta. Masyarakat biasa yang tidak bekerja sebagai pegawai negeri dan swasta dapat dilihat masih jarang menggunakan kain batik Jambi karena batik Jambi lebih sering digunakan pada saat tertentu saja contohnya seperti acara ulang tahun Jambi, acara kebudayaan Jambi dan sebagainya. Dari fenomena tersebut, perlu diketahui apa yang menjadi faktor kain batik Jambi jarang dibeli dan digunakan masyarakat Jambi sendiri dan hanya orang-orang tertentu saja yang membeli kain batik Jambi.

Terdapat beberapa faktor yang dapat menjadi penyebab permintaan konsumen yaitu masyarakat jambi sendiri akan kain batik Jambi masih rendah. Beberapa faktor yang dapat mempengaruhi permintaan konsumen antara lain harga barang itu sendiri, pendapatan konsumen, harga barang lain, selera, dan lain-lain. Semua faktor ini dapat mempengaruhi permintaan konsumen (Sukirno, 2010).

Kota Jambi memiliki sebelas Kecamatan diantaranya Telanai Pura, Jambi Selatan, Jambi Timur, Pasar Jambi, Danau Teluk, Jelutung, Kota Baru, Danau Sipin, Paal Merah, Pelayangan dan Alam Barajo (BPS Kota Jambi, 2018). Dari sebelas Kecamatan tersebut salah satu Kecamatan yang terdapat banyak jumlah penduduk adalah Kecamatan Alam Barajo. Pada tahun 2018 tercatat Kecamatan tersebut memilki penduduk sebanyak 97.184 jiwa, banyaknya Jumlah penduduk dalam suatu daerah merupakan salah satu faktor yang dapat mempengaruhi permintaan. Kecamatan Alam Barajo terdiri dari 5Kelurahan yakni Mayang Mangurai, Kenali Besar, Rawasari, Beliung dan Bagan Pete (Kecamatan Alam Barajo Dalam Angka, 2018).

Dalam penelitian ini penulis memilih melakukan penelitian di Kelurahan Mayang Mangurai dikarenakan Kelurahan Mayang Mangurai merupakan salah satu kelurahan dengan jumlah penduduk terbanyakdibandingkan dengan kelurahan lainnya. Kelurahan tersebut memiliki jumlah penduduk sebanyak 20.287 jiwa dari 5.863 KK. Karena Kelurahan Mayang Mangurai merupakan daerah yang terdapat banyak perumahanperumahan bagusdengan rata-rata pekerjaan masyarakatnya adalah sebagai pegawai negeri dan swasta, maka dengan pekerjaan tersebut tingkat kebutuhan dan penggunaan batik dalam kegiatan bekerja tentu lebih tinggi dibandingkan dengan orang yang tidak bekerja sebagai pegawai negeri dan swasta, sehingga tingkat permintaan kain batik 
Jambi lebih banyak di minta pada orang-orang yang bekerja sebagai pegawai negeri dan swasta.

\section{METODE}

Jenis data yang digunakan dalam penelitian ini adalah Data Primer, pengumpulan data dengan jenis data cross sectiondimana dalam memperoleh informasi dan data-data berasal dari responden yang telah dijadikan sampel menggunakan daftar pertanyaanpertanyaan (kuesioner).Data penelitian bersumber dari objek penelitian yang dikumpulkan melalui wawancara dengan responden yang berada di Kelurahan Mayang Mangurai Kecamatan Alam Barajo Kota Jambi dan data sekunder dari Badan Pusat Statistik Provinsi Jambi, Dinas Perindustrian dan Perdagangan Provinsi Jambi, Dinas Perdagangan dan Perindsutrian Kota Jambi, Journal Ekonomi dan Pembangunan, dan lain sebagainya.Metode penarikan sampel yang digunakan yaitu populasi yang merupakan ibu-ibu yang bekerja sebagai pegawai negeri dan swasta di 6 RT di Kelurahan Mayang Mangurai sebanyak 120 orang dan sampel dengan menggunakan metode slovin dengan standar error sebesar 10\% diperoleh sebanyak 55 responden. Metode analisis yang digunakan yaitu analisis deskriptif dan regresi linear berganda.

Menganalisis pengaruh harga kain batik Jambi,pendapatan konsumen, dan harga barang substitusi terhadap permintaan kain batik Jambi, digunakan model regresi dengan persamaan sebagai berikut :

\section{LOGPKB $_{i}=\beta_{0}+\beta_{1}$ LOGHRG $_{i}+\beta_{2}$ LOGPDK $_{i}+\beta_{3}$ LOGHBS $_{i}+$ ei}

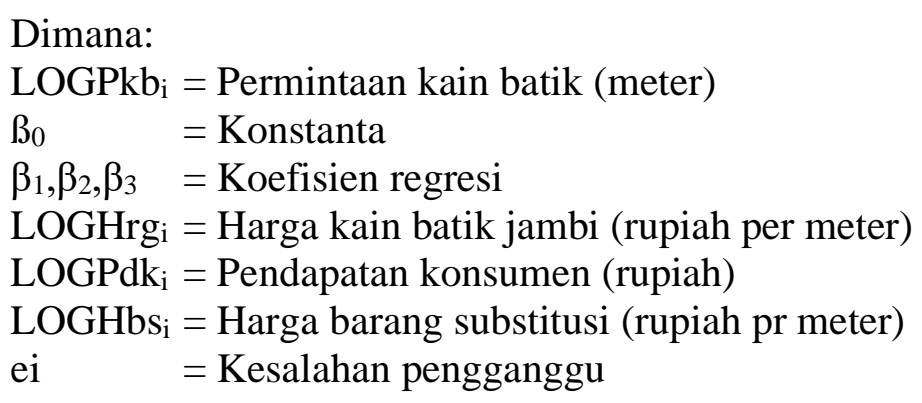

\section{HASIL DAN PEMBAHASAN}

\section{Karakteristik konsumen kain batik jambi serta hubungannya dengan permintaan kain batik Jambi}

Analisis deskripsi adalah langkah pertama yang perlu dilakukan untuk mengetahui bagaimana gambaran umum data yang telah dikumpulkan dari responden. Karakteristik responden dalam penelitian ini akan mengambil responden yaitu yang merupakan konsumen kain batik Jambi yang berlokasi di Kelurahan Mayang Mangurai Kecamatan Alam Barajo Kota Jambi yang berjumlah sebanyak 55 responden. Distribusi responden dimaksudkan untuk melihat karakeristik konsumen kain batik Jambi di Kelurahan Mayang Mangurai yaitu seperti karakteriktik umur responden, karakteristik tingkat pendidikan terakhir responden,karakteristik pekerjaan responden, karakteristik jumlah anggota keluarga responden, dan karakteristik pendapatan responden.

\section{Umur}

Distribusi responden berdasarkan kelompok umur konsumen kain batik Jambi di Kelurahan Mayang Mangurai Kecamatan Alam Barajo Kota Jambi tahun 2018, yaitu 
karakteristik konsumen yang menafsirkan kategori umur konsumen dalam membeli kain batik Jambi yang mana dalam setiap kategori umur terdapat perbedaan jumlah permintaan kain batik Jambi, dan kategori karakteristik responden tersebut dapat dilihat pada Tabel berikut:

Tabel 2. Distribusi responden berdasarkan kelompok umur konsumen kain batik Jambi diKelurahan Mayang Mangurai Kecamatan Alam Barajo Kota Jambi tahun 2018

\begin{tabular}{cccccc}
\hline $\begin{array}{c}\text { Umur } \\
\text { Permintaan }\end{array}$ & $\mathbf{2 0 - 3 0}$ & $\mathbf{3 1}-\mathbf{4 0}$ & $\mathbf{4 1}-\mathbf{5 0}$ & $\mathbf{5 1} \mathbf{- 6 0}$ & $\begin{array}{c}\text { Total jumlah } \\
\text { permintaan }\end{array}$ \\
\hline 2 Meter & 1 & 5 & 1 & 1 & 8 \\
3 Meter & 4 & 1 & 0 & 1 & 6 \\
4 Meter & 1 & 4 & 8 & 2 & 15 \\
5 Meter & 0 & 6 & 1 & 0 & 7 \\
6 Meter & 2 & 2 & 4 & 7 & 15 \\
> 7 Meter & 0 & 1 & 2 & 1 & 4 \\
\hline Jumlah responden & & & & & $\mathbf{5 5}$ \\
menurut umur & $\mathbf{8}$ & $\mathbf{1 9}$ & $\mathbf{1 6}$ & $\mathbf{1 2}$ & $\mathbf{5 5}$ \\
\hline Persentase (\%) & $\mathbf{1 4 , 5 4}$ & $\mathbf{3 4 , 5 4}$ & $\mathbf{2 9 , 1 0}$ & $\mathbf{2 1 , 8 2}$ & $\mathbf{1 0 0 , 0 0}$ \\
\hline
\end{tabular}

Sumber : Data diolah, 2018

Berdasarkan Tabel 2, terlihat bahwa distribusi berdasarkan kelompok umur konsumen kain Batik Jambi di KelurahanMayang Mangurai dengan jumlah responden sebanyak 55, menunjukkan kelompok umur konsumen kain batik Jambi tertinggi yaitu antara 31-40 tahun sebanyak 19 atau 34,54\% responden dan pada umur ini permintaan paling banyak terdapat pada kisaran 5 meter yaitu sebanyak 6 responden dan paling sedikit berada pada kisaran $>7$ meter yaitu 1 responden dari total 19 responden dan jumlah konsumen kain batik Jambi terendah yaitu antara 20-30 tahun sebanyak 8 atau $14,54 \%$ responden dengan jumlah permintaan paling banyak terdapat pada kisaran 3 meter yaitu sebanyak 4 responden dan paling sedikit terdapat pada kisaran 5 meter dan $>7$ meter yaitu 0 responden dari total 8 responden.Dan dari total keseluruhan jumlah permintaan kain batik Jambi berdasrakan umur paling banyak terdapat pada kisaran 4 dan 6 meter dengan total jumlah permintaan sama-sama sebanyak 15 responden dari total 55 responden. Hal ini menunjukkan bahwa rata-rata umur ibu-ibu dalam penelitian ini adalah 42 tahun dengan total jumlah permintaan kain batik Jambi terbanyak terdapat pada kisaran 4 dan 6 meter.Alasanya adalah bahwa pada umur 42 tahun ibu-ibu pekerja masih berada pada umur yang sangat produktif dalam bekerja sehingga ibu-ibu yang berada pada umur tersebut lebih aktif dalam megikuti kegiatan-kegiatan perkantoran seperti acara dinas dan sebagainya. Dengan begitu rata-rata kain batik Jambi lebih banyak digunakan oleh ibu-ibu pekerja yang berada pada umur tersebut.

\section{Pendidikan}

Distribusi responden berdasarkan kelompok tingkat pendidikan konsumen kain batik Jambi di Kelurahan Mayang Mangurai Kecamatan Alam Barajo Kota Jambi Tahun 2018, yaitu karakteristik konsumen yang menafsirkan kategori tingkat pendidikan terakhir konsumen dalam membeli kain batik Jambi yang mana dalam setiap kategori tersebut terdapat perbedaan jumlah permintaan kain batik Jambi, dan kategori 
karakteristik responden berdasarkan kelompok tingkat pendidikan dapat dilihat pada Tabel berikut:

Tabel 3. Distribusi responden berdasarkan pendidikan terakhir konsumen kain batik Jambi di Kelurahan Mayang Mangurai Kecamatan Alam Barajo Kota Jambi tahun 2018

\begin{tabular}{cccccc}
\hline Pendidikan & SLTA & D3 & S1 & S2 & $\begin{array}{c}\text { Total jumlah } \\
\text { permintaan }\end{array}$ \\
Permintaan & & & & & 8 \\
2 Meter & 4 & 0 & 4 & 0 & 6 \\
3 Meter & 1 & 1 & 4 & 0 & 15 \\
4 Meter & 1 & 3 & 9 & 2 & 7 \\
5 Meter & 2 & 1 & 4 & 0 & 4 \\
6 Meter & 1 & 2 & 10 & 2 & $\mathbf{5 5}$ \\
> Meter & 0 & 0 & 3 & 1 & $\mathbf{5 5}$ \\
\hline $\begin{array}{c}\text { Jumlah responden } \\
\text { menurut }\end{array}$ & $\mathbf{9}$ & $\mathbf{7}$ & $\mathbf{3 4}$ & $\mathbf{5}$ & \\
$\begin{array}{c}\text { pendidikan } \\
\text { Persentase (\%) }\end{array}$ & $\mathbf{1 6 , 3 6}$ & $\mathbf{1 2 , 7 3}$ & $\mathbf{6 1 , 8 2}$ & $\mathbf{9 , 0 9}$ & $\mathbf{1 0 0 , 0 0}$ \\
\hline
\end{tabular}

Sumber : Data diolah, 2018

Berdasarkan Tabel 3, distribusi responden berdasarkan tingkat pendidikan terakhir di Kelurahan Mayang Mangurai dengan jumlah responden sebanyak 55, menunjukkan jumlah konsumen kain Batik Jambi tertinggi dengan tingkat pendidikan terakhir yaitu S1 sebanyak 34 atau $61,82 \%$ responden dengan jumlah permintaan paling banyak terdapat pada kisaran 6 meter yaitu sebanyak 10 responden dan paling sedikit berada pada kisaran $>7$ meter yaitu 3 responden dari total 34 responden dan jumlah konsumen kain batik Jambi terendah dengan tingkat pedidikan terakhir yaitu S2 sebanyak 5 atau $9,09 \%$ responden dengan jumlah permintaan paling banyak terdapat pada kisaran 4 dan 6 meter yaitu sama-sama sebanyak 2 responden dan paling sedikit berada pada kisaran 2,3 dan 4 meter yaitu 0 responden dari total 5 responden. Dari total keseluruhan jumlah permintaan kain batik Jambi berdasarkan tingkat pendidikan terakhir paling banyak terdapat pada kisaran 4 dan 6 meter dengan total jumlah permintaan sama-sama sebanyak 15 responden dari total 55 rseponden. Hal ini menunjukkan bahwa rata-rata pendidikan terakhir ibu-ibu pekerja adalah S1dengan total jumlah permintaan kain batik Jambi terbanyak terdapat pada kisaran 4 dan 6 meter.Dalam penelitian ini permintaan pada kisaran 6 dan $>7$ meter paling banyak terdapat pada kelompok tingkat pendidikan S1 dan S2, tingginya tingkat pendidikan seseorang dapat mempengaruhibesarnya pendapatan yang diterima yang mana dari besarnya tingkat pendapatan yang diperoleh oleh seseorang maka dapat mempengaruhi permintaan seseorang terhadap suatu barang tertentu seperti salah satunya permintaan terhadap kain batik Jambi, yang mana kain batik Jambi merupakan salah satu barang yang diperlukan oleh seorang pekerja untuk mendukung dalam pekerjaanya.

\section{Pekerjaan}

Distribusi responden berdasarkan kelompok pekerjaan konsumen kain batik Jambi di Kelurahan Mayang Mangurai Kecamatan Alam Barajo Kota Jambi Tahun 2018, yaitu karakteristik konsumen yang menafsirkan kategori pekerjaan konsumen dalam membeli kain batik Jambi yaitu antara PNS dan pegawai Swasta yang mana dalam setiap kategori 
tersebut terdapat perbedaan jumlah permintaan kain batik Jambi, dan kategori karakteristik responden berdasarkan pekerjaan konsumen tersebut dapat dilihat pada Tabel berikut:

Tabel 4. Distribusi responden berdasarkan pekerjaan konsumen kain batik Jambi di Kelurahan Mayang Mangurai Kecamatan Alam Barajo Kota Jambi tahun 2018

\begin{tabular}{cccc}
$\begin{array}{c}\text { Pekerjaan } \\
\text { Permintaan }\end{array}$ & PNS & SWASTA & $\begin{array}{c}\text { Total jumlah } \\
\text { permintaan }\end{array}$ \\
\hline 2 Meter & 4 & 4 & 8 \\
3 Meter & 3 & 3 & 6 \\
4 Meter & 10 & 5 & 15 \\
5 Meter & 5 & 2 & 7 \\
6 Meter & 12 & 3 & 15 \\
7 Meter & 4 & 0 & $\mathbf{5 5}$ \\
\hline $\begin{array}{c}\text { Jumlah } \\
\text { responden }\end{array}$ & & & $\mathbf{5 5}$ \\
menurut & $\mathbf{3 8}$ & $\mathbf{1 7}$ & $\mathbf{1 0 0 , 0 0}$ \\
pekerjaan & & &
\end{tabular}

Sumber : Data diolah, 2018

Berdasarkan Tabel 4, dilihat bahwa distribusi responden berdasarkan pekerjaan di Kelurahan Mayang Mangurai menunjukkan jumlah konsumen kain Batik Jambi dengan pekerjaan antara PNS dan Swasta paling tinggi yaitu yang bekerja sebagai PNS sebanyak 38 atau 69,10\% respondendengan permintaan paling banyak terdapat pada kisaran 6 meter yaitu sebanyak 12 responden dan paling sedikit terdapat pada kisaran 3 meter yaitu 3 responden dari total 38 responden dan jumlah konsumen kain batik Jambi terendah yaitu yang bekerja Swasta sebanyak 17 atau 30,90\% responden dengan jumlah permintaan paling banyak terdapat pada kisaran 4 meter yaitu sebanyak 5responden dan paling sedikit terdapat pada kisaran $>7$ meter yaitu 0 responden dari total 17 responden.Dari total keseluruhan jumlah permintaan kain batik Jambi berdasarkan pekerjaan konsumen kain batik Jambi paling banyak terdapat pada kisaran 4 dan 6 meter dengan total jumlah permintaan sama-sama sebanyak 15 responden dari total 55 responden.Hal ini menunjukkan bahwa rata-rata ibu-ibu dalam penelitian ini memilki pekerjaan sebagai PNS dengan total jumlah permintaan kain batik Jambi terbanyak berada pada kisaran 4 dan 6 meter.

\section{Jumlah anggota keluarga}

Distribusi responden berdasarkan jumlah anggota keluarga konsumen kain batik Jambi di Kelurahan Mayang Mangurai Kecamatan Alam Barajo Kota Jambi Tahun 2018, yaitu karakteristik konsumen yang menafsirkan kategori jumlah anggota keluarga yang dimiliki setiap konsumen yang mana dalam setiap kategori tersebut terdapat perbedaan jumlah permintaan kain batik Jambi, dan kategori karakteristik responden berdasarkan jumlah anggota keluarga tersebut dapat dilihat pada Tabel berikut: 
Tabel 5. Distribusi responden berdasarkan jumlah anggota keluarga konsumen kain batik Jambi di Kelurahan Mayang Mangurai Kecamatan Alam Barajo Kota Jambi tahun 2018

\begin{tabular}{ccccc}
\hline JAK & $\mathbf{2 - 3}$ & $\mathbf{4 - 5}$ & $\mathbf{6 - 7}$ & $\begin{array}{c}\text { Total jumlah } \\
\text { permintaan }\end{array}$ \\
\hline Permintaan & 1 & 7 & 0 & 8 \\
2 Meter & 6 & 0 & 0 & 6 \\
3 Meter & 3 & 12 & 0 & 75 \\
4 Meter & 2 & 5 & 0 & 15 \\
5 Meter & 8 & 6 & 1 & 4 \\
6 Meter & 0 & 2 & 2 & $\mathbf{5 5}$ \\
>7 Meter & $\mathbf{2 0}$ & $\mathbf{3 2}$ & $\mathbf{3}$ & $\mathbf{5 5}$ \\
$\begin{array}{c}\text { Jumlah } \\
\text { responden }\end{array}$ & & & & \\
menurut JAK & $\mathbf{3 6 , 3 6}$ & $\mathbf{5 8 , 1 8}$ & $\mathbf{5 , 4 6}$ & $\mathbf{1 0 0 , 0 0}$ \\
\hline Persentase (\%) & & & & \\
\hline
\end{tabular}

Sumber : Data diolah, 2018

Berdasarkan Tabel 5, dapat dilihat bahwa distribusi responden menunjukkan jumlah konsumen kain Batik Jambi dengan jumlah anggota keluarga paling besar yaitu 4-5 orang sebanyak 32 atau 58,18\% responden dengan permintaan paling banyak terdapat pada kisaran 6 meter yaitu sebanyak 12 responden dan paling sedikit terdapat pada kisaran 3 meter yaitu 0 responden dari total 32 responden dan jumlah konsumen kain batik Jambi dengan jumlah anggota keluarga paling sedikit yaitu 6-7 orang sebanyak 3 responden atau 5,46\% responden dengan jumlah permintaan paling banyak terdapat pada kisaran $>7$ meter yaitu sebanyak 2 responden dan paling sedikit terdapat pada kisaran 2 sampai 5 meter yaitu 0 responden dari total 3 responden dengan jumlah anggota keluarga 6-7 orang.Dari total keseluruhan jumlah permintaan kain batik Jambi berdasarkan jumlah anggota keluarga paling banyak terdapat pada kisaran 4 dan 6 meter dengan total jumlah permintaan sama-sama sebanyak 15 responden dari total 55 responden. Hal ini menunjukkan bahwa rata-rata ibu-ibu dalam penelitian ini memilikijumlah anggota keluarga sebanyak 4 orang dengan total jumlah permintaan kain batik Jambi terbanyak berada pada kisaran 4 dan 6 meter. Alasannya adalah bahwa semakin banyak jumlah anggota keluarga seseorang maka semakin banyak permintaan akan suatu barang, termasuk salah satunya adalah permintaan akan suatu barang yaitu barang berupa kain batik Jambi.

\section{Pendapatan}

Distribusi responden berdasarkan tingkat pendapatan konsumen kain batik Jambi di Kelurahan Mayang Mangurai Kecamatan Alam Barajo Kota Jambi Tahun 2018, yaitu karakteristik konsumen yang menafsirkan kategori berdasaran bersarnya pendapatan yang diperoleh konsumen dalam membeli kain batik Jambi yang mana dalam setiap kategori tersebut terdapat perbedaan jumlah permintaan kain batik Jambi, dan kategori karakteristik responden berdasarkan kelompok tingkat pendapatan tersebut dapat dilihat pada Tabel 6.

Berdasarkan Tabel 6, dilihat bahwa distribusi responden menunjukkan yang memiliki pendapatan tertinggi yaitu antara Rp.3.001.000-4.000.000 per bulan selama setahun sebanyak 23 atau 4,82\% respondendengan permintaan paling banyak terdapat pada kisaran 4 meter yaitu sebanyak 9 responden dan paling sedikit terdapat pada 
kisaran $>7$ meter yaitu 0 responden dari total 23 responden dan jumlah konsumen kain batik Jambi yang memiliki pendapatan paling sedikit yaitu Rp.>5.000.000 rata-rata per bulan selama setahun sebanyak 8 atau $14,53 \%$ responden dengan jumlah permintaan paling banyak terdapat pada kisaran 6 meter yaitu sebanyak 4 responden dan paling sedikit berada pada kisaran 2,3 dan $>7$ meter yaitu 0 responden dari total 8 responden. Dari total keseluruhan jumlah permintaan kain batik Jambi berdasarkan pendapatan paling banyak terdapat pada kisaran 4 dan 6 meter dengan total jumlah permintaan sama-sama sebanyak 15 responden dari total 55 responden. Hal ini menunjukkan adapunrata-rata pendapatan ibu-ibu dalam penelitian ini adalah Rp. 4.240.000 rata-rata per bulan dalam setahundengan total jumlah permintaan kain batik Jambi terbanyak berada pada kisaran 4 dan 6 meter.

Tabel 6. Distribusi responden berdasarkan pendapatan konsumen kain batik Jambi di Kelurahan Mayang Mangurai Kecamatan Alam Barajo Kota Jambi tahun 2018

\begin{tabular}{|c|c|c|c|c|c|}
\hline $\begin{array}{l}\text { Pendapatan } \\
\text { Permintaan }\end{array}$ & $\begin{array}{c}2.001 .000 \\
- \\
3.000 .000\end{array}$ & $\begin{array}{c}3.001 .000 \\
- \\
4.000 .000\end{array}$ & $\begin{array}{c}4.001 .000 \\
- \\
5.000 .00\end{array}$ & $\begin{array}{c}>5.000 .00 \\
0\end{array}$ & $\begin{array}{c}\text { Total } \\
\text { jumlah } \\
\text { permintaan }\end{array}$ \\
\hline 2 Meter & 3 & 4 & 1 & 0 & 8 \\
\hline 3 Meter & 4 & 2 & 0 & 0 & 6 \\
\hline 4 Meter & 2 & 9 & 1 & 3 & 15 \\
\hline 5 Meter & 2 & 2 & 2 & 1 & 7 \\
\hline 6 Meter & 0 & 6 & 5 & 4 & 15 \\
\hline$>7$ Meter & 0 & 0 & 4 & 0 & 4 \\
\hline $\begin{array}{c}\text { Jumlah responden } \\
\text { menurut } \\
\text { pendapatan }\end{array}$ & 11 & 23 & 13 & 8 & 5555 \\
\hline Persentase (\%) & 20 & 41,82 & 23,63 & 14,53 & 100,00 \\
\hline
\end{tabular}

Sumber : Data diolah, 2018

\section{Analisis faktor-faktor yang mempengaruhi permintaan kain batik Jambi}

\section{Analisis regresi}

Hasil perhitungan regresidalam penelitian ini dapat di lihat pada Tabel 7,dengan menggunakan regresi liniear berganda dengan tingkat signifikansi sebesar $\alpha=5 \%$ yaitusebagai berikut:

Tabel 7. Hasil regresi permintaan kain batik Jambi

\begin{tabular}{lllll}
\hline \multicolumn{1}{c}{ Variable } & Coefficent & Std. Error & t-Statistic & Prob. \\
\hline \multicolumn{1}{c}{ C } & -3.538825 & 3.535380 & -1.000974 & 0.3216 \\
LOG(HRG) & -0.786343 & 0.191412 & -4.108112 & 0.0001 \\
LOG(PDK) & 0.604455 & 0.162599 & 3.717461 & 0.0005 \\
LOG(HBS) & 0.448897 & 0.173528 & 2.586886 & 0.0126 \\
\hline $\mathrm{R}^{2}$ & $=0.480829$ & $(-4.108112)$ & $(3.717461)$ & $(2.586886)$ \\
T-stat & $=(-1.000970)$ & $(0.0001)$ & $(0.0005)$ & $(0.0126)$ \\
t-prob & $=(0.3216)$ & & & \\
F-stat & $=15.74454$ & & & \\
F-prob & $=0.000000$ & & & \\
\hline
\end{tabular}

Sumber: Data diolah, 2018 
Berdasarkan Tabel 7, maka dapat di peroleh persamaan regresi sebagai berikut:

\section{LOGPKB $_{i}=-3.538825-0.786343$ LOGHRG $_{i}+0.604455$ LOGPDK $_{i}+0.448897$ LOGHBS $_{\text {i }}$}

Persamaan regresi linear tersebut dapat diinterpretasikan sebagai berikut:

Nilai Konstanta sebesar - 3.538825 memberikan arti bahwa jika HRG (harga kain batik Jambi), PDK (pendapatan konsumen), HBS (harga barang substitusi) diasumsikan $=0$, maka permintaan kain batik Jambi (PKB) akan turun sebesar 3.538825 meter.

Variabel bebas HRG (harga kain batik Jambi) mempunyai koefisien regresi sebesar -0.786343 , memberikan arti bahwa harga kain batik Jambi berpengaruh negatif terhadap permintaan kain batik Jambi di Kelurahan Mayang Mangurai dan besar probabilita 0,0001 signifikan pada $\alpha=5 \%$. Hal ini menunjukkan bahwa setiap penambahan 1 rupiah harga kain batik Jambi maka akan terjadi penurunan permintaan sebesar 0.837227 rupiah.

Variabel bebas PDK (pendapatan konsumen) mempunyai koefisien sebesar 0.604455, memberikan arti bahwa pendapatan konsumen berpengaruh positif terhadap permintaan kain batik Jambi di Kelurahan Mayang Mangurai dan besar probabilita 0,0005 signifikan pada $\alpha=5 \%$. Hal ini menunjukkan bahwa setiap penambahan 1 rupiah pendapatan konsumen maka akan terjadi kenaikan permintaan sebesar 0.604455 rupiah.

Variabel bebas HBS (harga barang substitusi) mempunyai koefisien sebesar 0.448897, memberikan arti bahwa harga barang substitusi berpengaruh positif terhadap permintaan kain batik Jambi di Kelurahan Mayang Mangurai dan besar probabilita 0,0126 signifikan pada $\alpha=5 \%$. Hal ini menunjukkan bahwa setiap penambahan 1 rupiah harga barang substitusi maka akan terjadi kenaikan permintaan sebesar 0.448897 rupiah.

\section{Pengujian asumsi klasik}

\section{Uji multikolinearitas}

Muktikolinearitas sebagai suatu keadaan dimana terjadi korelasi liniearitas yang "perfect" atau exact diantara sebagian atau semua variabel bebas dalam model regresi. Setelah hasil estimasi maka dapat dilakukan uji Multikolinearitas yang dapat dilihat dari nilai varians inflation factor (VIF) sebagai berikut:

Tabel 8.Hasil regresi multikolineritas

\begin{tabular}{cccc}
\hline Variable & $\begin{array}{c}\text { Coefficient } \\
\text { Variance }\end{array}$ & $\begin{array}{c}\text { Uncentered } \\
\text { VIF }\end{array}$ & $\begin{array}{c}\text { Centered } \\
\text { VIF }\end{array}$ \\
\hline C & 12.49891 & 7590.416 & NA \\
LOG(HRG) & 0.036639 & 2926.900 & 1.023197 \\
LOG(PDK) & 0.026438 & 3722.744 & 1.094433 \\
LOG(HBS) & 0.030112 & 2089.140 & 1.086107 \\
\hline
\end{tabular}

Sumber : Data diolah, 2018

Dari Tabel 8 menunjukkan bahwa hasil nilai VIF variabel harga kain batik Jambi (HRG) sebesar 1.088657, pendapatan konsumen (PDK) sebesar1.094433, dan harga 
barang substitusi (HBS) sebesar 1.086107 terhadap permintaan kain batik Jambi kurang dari 10, maka dapat dinyatakan tidak terjadi gejala multikolinearitas dalam penelitian.

\section{Uji heterokedastisitas}

Ujiheterokedastisitas digunakan untuk melihat ada atau tidaknya penyimpangan dari asumsi klasik. Jika terjadi heterokedastisitas maka penaksir OLS tetap tak bias dan konsisten, tetapi penaksir tadi tidak lagi efisien baik dalam sampel kecil maupun besar. Model heterokedastisitas dapat dilihat pada Tabel berikut:

Tabel. 9.Hasil regresi heterokedastisitas

\section{Heteroskedasticity Test: Breusch-Pagan-Godfrey}

\begin{tabular}{llll} 
F-statistic & 0.476478 & Prob. F(3,51) & 0.7000 \\
Obs*R-squared & 1.499518 & Prob. Chi-Square(3) & 0.6824 \\
Scaled explained SS & 1.057435 & Prob. Chi-Square(3) & 0.7874 \\
\hline
\end{tabular}

Sumber : Data diolah, 2018

Pada Tabel 9 menunjukkan bahwa hasil probabilita Chi-Square lebih besar dari nilai $\alpha$ yang dipilih yaitu $0.6824>0,05$ dan tidak mengalami signifikan dalam model pengujian Breusch-Pagan-Godfey ini berarti variabel harga kain batik Jambi, pendapatan konsumen, dan harga barang substitusi terhadap permintaan kain batik Jambi di Kelurahan Mayang Mangurai tidak terdapat heterokedastisitas.

\section{Uji autokorelasi}

Uji autokorelasi dengan menggunakan metode Breusch-Godfeyumum dikenal dengan uji Lagrange Multiplier (LM). Masalah autokorelasi biasanya muncul dalam data time series meskipun tidak menutup kemungkinan juga pada data cross section. Berikut ini model Heterokedastisitas dapat dilihat pada Tabel berikut:

Tabel 10. Hasil regresi autokorelasi

\section{Breusch-Godfrey Serial Correlation LM Test}

\begin{tabular}{llll} 
F-statistic & 0.217818 & Prob. F(2,49) & 0.8050 \\
Obs*R-squared & 0.484670 & Prob. Chi-Square(2) & 0.7848 \\
\hline
\end{tabular}

Sumber : Data diolah, 2018

Pada Tabel 10 menunjukkan bahwa hasil nilai Probabilita Chi-Square lebih besar dari nilai $\alpha$ yang dipilih yaitu $0.7848>0,05$ dan tidak mengalami signifikan dalam model pengujian Breusch-Godfey Serial Correlation LM Test ini berarti variabel harga kain batik Jambi, pendapatan konsumen, dan harga barang substitusi terhadap permintaan kain batik Jambi di Kelurahan Mayang Mangurai tidak terdapat autokorelasi.

\section{Uji normalitas}

Hasil uji normalitas menunjukkan bahwa nilai Probabilita J-B hitung lebih besar dari nilai probabilitas $\alpha(0,05)$ dalam pendekatan Jorque-Berra test maka hipotesis yang menyatakan bahwa variabel penggangu adalah bersistribusi normal diterima. 


\section{Pengujian hipotesis}

\section{Uji signifikasi secara simultan (Uji-F)}

Hasil penelitian diperoleh nilai $\mathrm{F}$ hitung sebesar 15.74454 dengan probabilita sebesar $(0.000000)$ atau lebih kecil nilai $\alpha=0,05(0.000000<0,05)$, artinya $\mathrm{H}_{0}$ ditolak dan $\mathrm{H}_{\mathrm{a}}$ diterima pada tingkat keyakinan 95\%. Jadi dapat disimpulkan bahwa variabel harga kain batik Jambi, pendapatan konsumen, dan harga barang substitusi berpengaruh signifikan terhadap permintaan kain batik Jambi.

\section{Uji signifikansi secara parsial (Uji-t)}

Uji t digunakan untuk mengetahui signifikan pengaruh variabel independen (yaitu harga, pendapatan konsumen, dan harga barang substitusi) secara parsial (individu) terhadap variabel dependen (permintaan kain batik Jambi) yaitu dengan cara melihat signifikan $\alpha=5 \%$. Apabila tingkat signifikan lebih kecil dari $\alpha=5 \%$.

Hasil penelitian menjelaskan bahwa pengujian koefisien regresi variabel HRG (harga), dapat dilihat bahwa nilai t hitung sebesar -4.337806 dengan probabilita variabel HRG (harga) sebesar 0.0001 atau lebih kecil dari nilai $\alpha=5 \%(0.0002<0.05)$, maka $\mathrm{H}_{0}$ ditolak dan $\mathrm{H}_{\mathrm{a}}$ diterima. Artinya dapat disimpulkan bahwa secara parsial variabel harga memiliki pengaruh signifikan terhadap permintaan kain batik Jambi.

Koefisien regresi variabel PDK (pendapatan konsumen), dapat dilihat bahwa nilai t hitung sebesar 3.598057 dengan probabilita variabel PDK (pendapatan konsumen) sebesar 0.0007 atau lebih kecil dari nilai $\alpha=5 \%(0.0007<0.05)$, maka $\mathrm{H}_{0}$ ditolak dan $\mathrm{H}_{\mathrm{a}}$ diterima. Artinya dapat disimpulkan bahwa secara parsial variabel pendapatan konsumen memiliki pengaruh signifikan terhadap permintaan kain batik Jambi.

Koefisien regresi variabel HBS (harga barang substitusi), dapat dilihat bahwa nilai t hitung sebesar 2.571733dengan probabilita variabel HBS (harga barang substitusi) sebesar 0.0131 atau lebih kecil dari nilai $\alpha=5 \%(0.0131<0.05)$, maka $\mathrm{H}_{0}$ ditolak dan $\mathrm{H}_{\mathrm{a}}$ diterima. Artinya dapat disimpulkan bahwa secara parsial variabel harga barang substitusi memiliki pengaruh signifikan terhadap permintaan kain batik Jambi.

\section{Koefisien determinasi $\left(\mathbf{R}^{2}\right)$}

Hasil yang diperoleh angka R-Squared sebesar 0.480829atau 48,08\%. Dari koefisien determinasi $\mathrm{R}^{2}$ yang diperoleh dinyatakan bahwa variabel harga kain batik Jambi, pendapatan konsumen, dan harga barang substitusi terhadap permintaan kain batik Jambi hanya berpengaruh sebesar $48,08 \%$, sementara sisanya 51,92\% dipengaruhi oleh variabel lain yang tidak dimasukkan dalam model penelitian ini.

\section{KESIMPULAN DAN SARAN}

\section{Kesimpulan}

Berdasarkan karakteristik konsumen kain batik Jambi dari 55 responden konsumen kain batik Jambi di Kelurahan Mayang Mangurai Kecamatan Alam Barajo Kota Jambi diketahui bahwa rata-rata umur konsumen kain batik Jambi adalah 42 tahun. Rata-rata pendidikan terakhir konsumen kain batik Jambi yaitu S1. Rata-rata pekerjaan yang dimiliki konsumen kain batik Jambi adalah sebagai PNS. Rata-rata konsumen kain batik Jambi memiliki jumlah anggota keluarga 4 orang. Rata-rata pendapatan yang diperoleh konsumen kain batik Jambi antara Rp.4.240.000 per bulan. Berdasarkan hasil analisis menggunakan regresi linear berganda untuk melihat faktor-faktor yang 
mempengaruhi permintaan kain batik Jambi di Kelurahan Mayang Mangurai Kecamatan Alam Barajo Kota Jambi, maka diperoleh hasil sebagai berikut:

Faktor yang mempengaruhi permintaan kain batik Jambi di Kelurahan Mayang Manurai Kecamatan Alam Barajo Kota Jambi secara bersama-sama dipengaruhi oleh variabel harga (HRG), pendapatan konsumen (PDK), dan harga barang substitusi (HBS). Sedangkan secara parsial variabel harga (HRG), pendapatan konsumen (PDK), dan harga barang substitusi (HBS) juga memiliki pengaruh yang signifikan terhadap permintaan kain batik Jambi di Kelurahan Mayang Mangurai Kecamatan Alam Barajo Kota Jambi.

\section{Saran}

Agar meningkatkan permintaan kain batik Jambi di Kelurahan Mayang Mangurai, sebaiknya lebih memperhatikan apa saja faktor-faktor yang dapat mempengaruhi permintaan konsumen dengan baik agar permintaan akan kain batik Jambi dapat semakin meningkat dan lebih berkembang. Pengrajin/produsen hendaknya terus melakukan efisiensi biaya produksi agar harga dapat ditekan sehingga permintaan konsumen akan meningkat, selain itu pengrajin/produsen juga dapat memberikan berupa potongan harga kepada konsumen yang membeli dalam jumlah banyak agar konsumen semakin tertarik membeli kain batik Jambi. Pengrajin/produsen kain batik Jambi hendaknya dapat memproduksi berbagai variasi produk kain batik agar dapat menjaring lebih banyak konsumen dari berbagai tingkat pendapatan. Pengrajin/produsen hendaknya dapat terus berusaha meningkatkan kualitas produk kain batik Jambi sehingga meskipun harga kain batik Jambi lebih tinggi dibandingkan kain batik Jawa, akan tetapi konsumen tetap lebih memilih kain batik Jambi dikarenakan memiliki kualitas produk yang lebih baik.

\section{DAFTAR PUSTAKA}

Asosiasi Batik Jambi (ASBAJA). (2018). Permintaan kain batik Jambi. Kota Jambi: Jambi.

Badan Pusat Statistik (BPS). (2018). Profil Daerah Kota Jambi. Kota Jambi Dalam Angka. Provinsi Jambi: Jambi.

Badan Pusat Statistik (BPS). (2018). Data jumlah penduduk. Kecamatan Alam Barajo Dalam Angka. Provinsi Jambi: Jambi. Dalam : https://jambikota.bps.go.id. Diakses Tanggal 19 November 2018.

Dinas Perindustrian dan Perdagangan Provinsi Jambi, (2017). Data Industri Kecil dan Kerajinan Rumah Tangga Provinsi Jambi Tahun 2010-2016. Provinsi Jambi: Jambi.

Inun. (2017). Artikel. Omset Pengrajin Batik Jambi Capai 10 Juta Perbulan. Dalam MetroJambi.com. Diambil dari :https://metrojambi.com/read/2017/11/04/ 26228/omset-pengrajin-batik-jambi-capai-10-juta-perbulan. Diakses tanggal 30 Agustus 2018.

Megasari, Kartika Ayu. (2014). Kesiapan daya saing industri kecil dan menengah (IKM) Alas Kaki di Kota Mojokerto Menghadapi Pasar Bebas Asean, Jurnal Ilmiah Mahasiswa FEB Universitas Brawijaya. 2(2); 2-36.

Simorangkir, Iskandar. (2018). Artikel. UMKM sumbangkan 60 persen ke pertumbuhan ekonomi nasional, Dalam Liputan6.com. Diambil dari : https://www.liputan6. 
com/bisnis/read/3581067/umkm-sumbang-60-persen-ke-pertumbuhan-ekonominasional. Diakses tanggal 19 November 2018.

Sukirno, Sadono. (2010). Makro ekonomi. teori pengantar. Edisi Ketiga. PT. Raja Grasindo Perseda : Jakarta.

Soraya, Sarifah. (2015). Permintaan Batik Jambi Meningkat. Dalam FokusJambi.com, Diakses dalam :https://jambi.antaranews.com/berita/306002/permintaan-batikjambi-meningkat. Tanggal 30 Agustus 2018.

Zulfanetti, dkk. (2017). Model pengembangan usaha berkelanjutan UMK Batik Jambi melalui kajian efisiensi produksi. Universitas Jambi: Jambi. (tidak dipublikasi).

WP Rahayu, PH Prihanto, E Achmad. (2016).Faktor-faktor yang mempengaruhi penyerapan tenaga kerja pada industri batik di Kecamatan Danau Teluk Kota Jambi, e-Jurnal Ekonomi Sumberdaya dan Lingkungan 5 (3)

J Junaidi, Z Zulfanetti, H Hardiani. (2014).Analisis kondisi ketenagakerjaan di Provinsi Jambi, Fakultas Ekonomi dan Bisnis Universitas Jambi

S Sunargo, D Hastuti. (2019).Mengatasi perilaku kerja kontraproduktif melalui peran integratif politik organisasional dan kecerdasan emosional pada era revolusi industri 4.0, Jurnal Paradigma Ekonomika 14 (2), 45-54 